\title{
American Dental Association
}

National Cancer Institute

\section{Source}

National Cancer Institute. American Dental Association. NCI Thesaurus. Code C89797.

A professional association of dentists, committed to advancing the public's oral health, the ethical and scientific advancement of the field, and the professional advancement of its members. 